\title{
Strikes, injunctions and compliance orders: the Labour Relations Act 1987
}

\author{
Bevan Greenslade*
}

The paper begins by criticising aspects of recent articles which are taken as indicative of views other than of employers, on economic torts and the Labour Court. In particular, it respectfully doubts the propriety of Richardson, J's dissenting views in the Baking Trades case, and the correctness of the learned Judge's re-statement of the common thesis that industrial relations is a unique civil relationship which necessarily demands a separate labour jurisdiction. It then discusses some problems appearing in the first few month's application of the $1987 \mathrm{Act}$, particularly regarding remedies against strikes with simultaneous and multiple causes. The paper closes with an argument that striking is totally outdated.

The August 1987 issue of the New Zealand journal of industrial relations contained a series of valuable articles which deserve to be kept with the New Zealand Law Society "travelling roadshow" seminar on the Labour Relations Act 1987. However, they read with a certain consistency of attitude which sits uncomfortably with employers. Consequently, this first part of this paper seeks to provide critical, but respectful, comment from an employer viewpoint on each of the journal articles in turn.

\section{Sir Ivor Richardson - The role of the courts ${ }^{1}$}

Many employers disagree with some of His Honour's comments. The following explains why.

\section{The continuing relationship"}

His Honour emphasises the "continuing relationship" as crucial to "the employment of labour", in contrast with the "adversary method of conflict resolution [in] ... courts of general jurisdiction" which "focuses on the dispute itself rather than the continuing relationship". The continuing relationship is said to "require[s] specialised judges who

* Legal Advisor, New Zealand Employers' Federation. The views expressed are those of the writer, not the Federation.

1 Richardson, Sir Ivor (1987) The role of the courts in industrial relations New Zealand journal of industrial relations 12 (2):113-118. 
become steeped in the field and who work with those from union and employer ranks. ${ }^{2}$ City professionals removed from commerce might think that, but front-line managers, marketers and supervisors know there is usually a "continuing relationship" in commerce, just as with staff. While lawyers and other professionals make contracts, plain citizens do deals. The difference is a deal's on-going nature in contrast to the snapshot ideal of a contract. Nonetheless, traditional courts of general jurisdiction do look to black-letter law to resolve contractual snap-shots of such continuing deals.

So what, if anything, is it about employment courts which means they should, or are better equipped to, take a uniquely "continuing" view of employment disputes?

(a) The training of employment Court judges does not especially fit them for resolving employment disputes from a "continuing relationship" viewpoint. Their training is similar to that of general jurisdiction judges. ${ }^{3}$

(b) Industrial parties do not bring employment disputes to employment courts to get "continuing" decisions. Just as Jane and John Citizen bring their gripes to conventional civil courts to get a ruling on a problem which they can't sort out themselves, not (pace the popular penchant for everyone to 'counsel', and 'mediate') to get wide-ranging advice still less, God forbid, decisions - on their "continuing relationships".

(c) Deciding on continuing relationships gives the imaginative, aggressive disputant scope to manipulate the court as an active weapon in real-life relationship ${ }^{4}$

(d) His Honour refers to the lay members who used to sit with the judges on the Arbitration Court. In their submissions on the Labour Relations Bill, employers protested the tendency sometimes perceived of conciliation by the Court and adjudication by the conciliators, insisting that the Court was there to adjudicate disputes (of right), not to arbitrate or mediate or conciliate.

(e) Lay advocates in employment courts bring a penumbra of union or employer views, in addition to legal argument. Sometimes when the prime parties' dispute has sharp collective significance (especially ideological or tactical), the union and employer central organisations are attracted, which is provided for in the statute.

(f) Plain citizens in dispute with one another know that no third party could ever understand fully the real ramifications of their "continuing relationships". That is why they bring, not their relationship for counselling, but their dispute for adjudication.

The unique strength and prime function of any court lies in its use of adversarial trial procedures to bring forth facts through evidence publicly examined on oath, to advance arguments of statute and case law, to apply those to the tested facts, and to then sift all that with unbiased critical logic to arrive at a legal decision on the evidenced facts which is

2 This view is common. For example, it is repeated in Vranken and Hince, 1987 which also refers to comments of the Minister of Labour, the Hon. Stan Rodger, during the second reading of the 1986 Bill, reported in The Dominion, 13 May 1987, p.2, "that buying and selling labour did not amount to just another economic market ... [it] had an additional element, namely the need for a continuing working relationship between the buyers and sellers..

3 Only one general jurisdiction speciality, the Family Court engages in particular training in sensitising the judiciary to human relationships. Ironically, it probably has more to do with relationships which are dis- continuing, than continuing !

4

Family Court parties are a prime example. Employment courts can be another. 
consistent with prior similar cases. That the decision as to liability should be of strict legal rationality, in no way runs counter to the application of a remedy which accords with "equity and good conscience". For the black letter mentality to prevail to the point of liability, then to be overtaken by equitable remedies, seems a desirable attitude for courts of both employment and general jursidiction. So employment disputes and courts are not inherently unique vis-a-vis general legal problems and fora. Quite the contrary.

\section{"large employers with their greater economic power"}

It is surprising to see such a hoary chestnut fall from such a height Large employers have great economic power, but so do large unions. And large employers are also very vulnerable - and in ways and to degrees that large unions are not (primarily because of their privileged position of de facto compulsory union membership). ${ }^{5}$ There is no general, overwhelming advantage to employers. Often the contrary is true.

\section{"may even destroy effective unionism."}

The phrase"effective unionism" begs a vast number of questions. If used to justify strike action as the countervailing power to employers' "greater economic power", it is quite inadequate. Damaging as strikes are, they simply do not balance the fundamental employer power which comes from the employers fundamental function of organising satisfaction of consumer wants. The real cost of strikes is that they poison the workeremployer relationship in favour of the aggrandisement of more remote union officials' power, and reduce the shareholders' and employer's confidence which in turn inhibits investment and so reduces available jobs.

"Effective unionism" has nothing to do with strikes over inflating wage rate demands or unproductive manning levels, but rather the very sharpest critical analysis of management competence and board of director vision in conceiving and developing new products and services, in getting the most cost-productive plant, in putting together the most imaginative and risk-proof financing deals. Effective unionism in that sense would be a top-flight blend of investigative journalism, technological commentary, and broker's backroom financial analysis, aimed firmly at demanding capitalist excellence from the custodians of capital.

\section{The Baking Trades $v$ General Foods ${ }^{6}$ interim injunction}

The dissenting view in this case was that because the Arbitration Court was a specialist employment Court, employment disputes should first be litigated fully in it before finding their limited way to any collateral or superior Court. Until that route was first exhausted, there was no jurisdiction in the High Court to issue injunctions in labour disputes covered by the Industrial Relations Act. That view is quoted selectively ad nauseam both by

5 Typically, large employers are heavily capitalised employers. High capital/labour ratios are generally desirable becase the more the dollar backing-per-arm, the greater productivity and chance for profit. But conversely, high fixed capital investment is a hostage to the union activist. Pressure on the firm's windpipe cuts off the oxygen of its cash-flow, leaving it to choke on the sludge of its overheads, particularly its loan servicing costs.

6 New Zealand Baking Trades Employees IUW v General Foods Corporation (NZ) Ltd [1985] 2 NZLR 110. 
learned counsel and opportunistic activists. This paper provides a timely opportunity to state a contrary argument.

Firstly, the Industrial Relations Act never was a code governing employment. Acts that are codes have a simple means of stating so. ${ }^{7}$ The Industrial Relations Act did not so state. Its silence should be taken as clear indication against such a drastic and far-reaching inference, which would exclude (by mere inference) several, and some powerful, jurisdictions and remedies. Secondly, if the Industrial Relations Act was intended to preclude conventional injunctions, interim or otherwise, it could have said so, if not in 1973, then in any of the frequent amendments. After all, the employment court set up by the Industrial Relations Act was explicitly stated to be a Court of record, ${ }^{8}$ and despite the surprising characterisation of it as an "inferior court" in His Honour's Quality Pizzas judgment ${ }^{9}$, it is respectfully submitted that the learned Williamson,J. 's riposte in

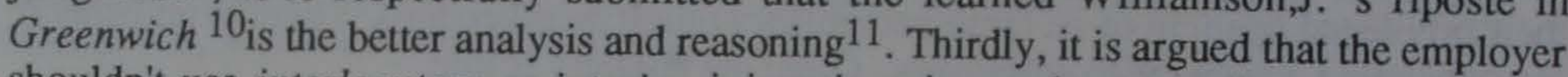
shouldn't use interlocutory or interim injunctions in employment disputes because in practice such a decision usually determines the ultimate decision - the parties don't return to litigate the final substantive issue. Why not? After all, the union sees the strike as an interim weapon to another, ultimate goal, which doesn't appear as the legal issue for reasoned decision in the Court. ${ }^{12}$ Fourthly and most importantly, the question created by

e.g. Crimes Act 1961, ss.9,11 and the Criminal Code Act 1893.

Industrial Relations Act 1973, s.32.

unreported, CA 17/83

[1983] ACJ 965 pp. 979-981

It should be noted that neither judgment invokes or discusses the concept of inherent jurisdiction or power, or refers to the article on that topic by Master I.H.Jacob in Current Legal Problems 1970, 23, and approved by the Court of Appeal in Taylor v A-G [1975] 2 NZLR 138.

The argument against injunctions in employment matters rests on the traditional reluctance of courts to give equitable remedies which amount to specific performance of a contract for personal services, partly on grounds of social policy and partly on the argument that the Court does not have power to actually enforce the carrying out of the personal services themselves (only to punish for contempt of a Court order). This view was overridden in some Canadian cases - (Winnipeg Builders Exchange v Operative Plasterers \& Cement Masons International Association (1964) 48 DLR (2.d) 173, Manitoba CA, 3 JJ; Winnipeg Builders' Exchange v International Brotherhood of Electrical Workers, Local Union (1966) 57 DLR (2.d) 141, Manitoba CA, 3JJ.; Prince Albert Pulp Co. Ltd. v Davidson (1970) 14 DLR (3d) 509, Saskatchewan CA, 3JJ.)- where the employers and the union had incorporated into their collective employment contract a 'peace clause'. The Courts there said that if the parties had entered into such a negative covenant with open eyes (citing Doherty v Allman (1878), 3 App.Cas. 709 at 720 , Lord Cairns, LC), there was no reason why the Courts should not enforce
it by granting an injunction.

It is respectfully suggested that the conventional judicial presumption of a blanket refusal to entertain specific performance of personal service agreements, is a judicial fiction when extended to collective agreements. Do judges really think employers negotiate collective agreements and settle the employment contract with the intention that the workers can withdraw their labour at
will ? This legal fiction will ? This legal fiction sees employment from the union point of view (not the workers' nor the employer's). Granted that judges are now bound by this rule; but its a chain of their own making, and one which is offensive to the commonsense of the people who actually work at the workplace. Neither employer nor worker would, in general, enter into a contract of employment realistically expecting to be able to strike at will. If that was discussed at the engagement interview, and the worker insisted upon that right, it's a fair bet the worker would never get engaged. So the doctrine is a judicial gift to the unions. 
His Honour was never an issue before the Court of Appeal. Exclusive Arbitration Court jurisdiction was argued initially in the High Court (see p.11 of the pre-Report judgment)

At the outset I accept Mr Colgan's submission that if this were a case which involved truly what might be called the interpretation or application of industrial law then this Court ought not to embark on an inquiry at all.

But it was not argued in the Court of Appeal. ${ }^{13}$ At the level of our highest local court, judicial courage should doubtless be welcomed; but it should fly on the wings of counsels' argument. Imagination alone should be expressed in seminars, conferences, or articles, rather than from the Bench on a case of specific facts.

A feature of the employment court's jurisdiction was the discretion to hear the central organisations. ${ }^{14}$ Central organisations have no such statutory rights of discretionary appearance in the Court of Appeal. His Honour himself actually over-rode one of the very features of the Act whose general pre-eminence he sought to promote. ${ }^{15}$ His Honour's dissenting judgment was truly obiter dictum. Before the 1987 Act, the courts of general jurisdiction had a clear power (and duty) to entertain injunction proceedings in industrial, no less than other, matters. The conventional Courts' reluctance to deal with industrial injunctions was viewed by employers at best with puzzlement. ${ }^{16}$

The Baking Trades case's twin forces of (a) apparent general judicial reluctance to order injunctions to stop strikes which were not lawful, and (b) His Honour's argument for prior jurisdiction of the employment court, led to a common view that Industrial Relations Act section 48 (2) (d) compliance orders needed first to be attempted and exhausted in the Arbitration Court before High Court injunctions were sought. That was unfortunate for two reasons:

(a) I believe it was mistaken. The High Court would issue injunctions in industrial disputes if the strict criteria were carefully met and proven; and (b) In practice, the Arbitration Court proceedings were notoriously slow compared to the commercial

13 I sat through the two days of the case and cannot recall the point being in issue. Indeed, Thorp,J. states -

The question whether the Industrial Relations Act 1973 gave the Arbitration Court exclusive jurisdiction in industrial disputes ... was not at any stage before the Court in these proceedings because both counsel for the appellants accepted that the Act did not have that effect.

One of the counsel accepted the High Court had a "last resort" jurisdiction; the other union counsel "did not contend that injunctions had no place in industrial law".

14 Explicitly recognised in both statutes.

15 And that merely through the inference of a privative interpretation of jurisdiction of a power not addressed at all in the said Act, namely injunctions.

16 And at worst by the most outspoken and less informed employers as bias, which in more extreme comment was phrased as a fear of decisions with political overtones. Since union voices expressed the opposite view on the rare occasions that injunctions were won by employers, one can feel sympathy for the judiciary caught between the rock and the hard places of involved public opinion. Yet that is ultimately the nature of their job - the reason for their judicial immunity from suit. 
requirement for speed ${ }^{17}$. It can be seen that in widely held employer opinion, the dissenting judgment was unjustified judicial activism, which ironically overlooked a crucial factor inherent in its own argument, and which generated a great deal of both strategic and tactical disadvantage for employers faced with declarations of industrial warfare. Perhaps the real wonder of it all is the union surprise and expressions of hurt when they accuse employers of recently becoming "aggressive"

\section{Gordon Anderson - Reception of economic torts into New Zealand labour law ${ }^{18}$}

The author reveals early a fundamental sympathy for the view that "the industrial relations system" is sufficiently important to desrve protection by legislation to survive ${ }^{19}$. Since there is no present likelihood of the industrial relations system not doing so, it may be presumed that means that trade unions especially deserve such protection. Anderson does not test the respective rights protected or threatened ${ }^{20}$ by "the intrusion of the common law", but it may be presumed that it is individual rights that are protected, and collective rights that are threatened. Employers do generally support such common law "intrusion" simply because they believe individual rights are fundamental. I suspect Anderson may not share that predisposition.

Employers acknowledge the common law to be based "on individual, property-based values and on a particular notion of freedom of contract" (p. 95). But that acknowledgment of an assumption is not, per se, a "flaw both in principle and in fact", or "a facade", as Anderson asserts. Still less is it an "attack[ on] the concept of democratic government". There is at least an arguable case that de-regulated commercial markets are more "democratic" and equitable than some of our merely political institutions of government, with their party-coagulated interests which have a propensity to trade off real equities in one social sector (e.g consumers' household economies through high personal

Even when urgency was determined upon, the sheer fewness and geographical concentration of that Court's judges compared to the large numbers and dispersion of High Court judges meant that 24 -hour or less responses were virtually impossible. So the unions usually could wring out a few more days' strike action, and the employer was left to carry losses for a further time. The argument that damages could be sought was often hollow, for unions were frequently "unions of straw", or alternatively very strong, concentrated unions could simply repeat the damage - this time over the temerity of the employer in trying to seek those damages.

Anderson, G (1987).The reception of the economic torts into New Zealand labour law: a preliminary discussion New Zealand journal of industrial relations 12 (2):89-100

"Until recently the major intervention by statute was intended to protect the industrial relations system from the potentially devastating intrusion of the common law." - p.92 (my emphasis).) While the industrial relations system is often useful to production economics, a threat that something might "devastate" it, by itself, does not persuade that that 'something' is therefore bad, or even worse that the present industrial relations system and its derivative 'industrial relations club' of academics (like Anderson) and interest-group advocates (like myself) therefore needs sustaining.

If Anderson wants to argue the superiority of political institutions over markets, that's fine, and a contribution on that point of political philosophy would be awaited with interest. But if his purpose is to persuade those of us who share the widely-known and openly-acknowledged basic assumption of common law (that it is individually-and property-based) that we are wrong in asserting common law superiority to "political" law, then it is logically not sufficient for him merely to state that assumption. It is not sufficient to leave the argument at that point with a rhetorical question as to the appropriateness in the New Zealand context of "incorporating these attitudes." 
income tax) against perceived equities in others (e.g universal, non-tested welfare benefits), to the ultimate damage of equity in both. ${ }^{21}$

Anderson characterises the failure of the Ocean Beach prosecutions as a "debacle", as though the criminal sanctions failed because they were inherently ineffective in industrial relations. This is not so. The sanctions failed to proceed because prosecutions were in the hands of the Labour Department, and there was not the political ${ }^{22}$ will to press multiple individual charges. ${ }^{23}$ It is to be noted that now there are civil, not criminal, remedies; and the suit lies at the initiative of a party, for example the employer. Litigation will be on the calculation of the individual party; the commercial, not the political, values will predominate. ${ }^{24}$ Where employers cannot recover commercial losses by strike action from unions, the new de-regulated commercial environment and the floating exchange rate will together mean, firstly that competition will lessen the suffering company's market share, and secondly that diversion or relocation of investment overseas will become more attractive or even a matter of survival. ${ }^{25}$

Economic torts were not ever actually "outside the mainstream of labour law in New Zealand". Such economic damage was usually able to be absorbed by companies supplying the local markets in the cost-plus pricing policies which then obtained. ${ }^{26} 27$ The economics torts were always part of the mainstream of law (if not labour law) in New Zealand; it was just that cross-subsidisation, welfarism and protectionism diverted the stream into an ox-bow for about 40 years. With deregulation and the return of market

22 Had all the defendants been involved in a riot causing extensive property damage, or some largescale affray involving assaults or multiple sexual connection, one could be sure the criminal process would not have been politically interfered with. Had the Ocean Beach prosecutions been in the hands of the company, it might have been a different question. The significant thing is that the Ocean Beach prosecutions were with the Department of Labourr.

23 Employers are aware of that (e.g. Ford v Northern Storepersons, cited by Anderson), as are the FOL also (e.g. Ken Douglas's complaint, Evening Post 24 November 1987). Employers who suffer gratuitous and illegal harm are no longer going to absorb those losses. They are going to recover them where appropriate. Further, it is arguable that the Companies Act Amendment 1982 , which put increased reponsibilities on directors and company officers, actually requires such steps from officers of limited liability corporations.

24 Consumers are now telling employers through the market-place that they must now no longer tolerate intransigent union head-banging attacks to advance the interests of only one of several factors of production.

25 That export companies, that is overseas consumers and customers, would eventually rebel seems not to have been realised, despite freezing companies' and farmers' despairing warnings. Eventually, the presence of the real wolf on export markets impinged. New Zealand's international competitive position dropped from 2 nd to 25 th. So much for those with faith that politicians, rather than competitive markets, should determine a country's balance of power of its production and consuming factors!

26 Also, there was a long period starting with World War II and the subsequent "full employment", when it was generally viewed as unacceptable for patriotic, humanist, socially sensitive, or simply 'political', reasons to seek legal compensation for economic damage suffered in industrial disputes.

27 It was the welfarism and protectionism which was out of step, not economic torts. The welfarist mentality and the protectionist economy blinkered and blanketed New Zealanders from world market realities. Economic torts are a civilised, legal response to the harsher realities of lost contracts and markets which can follow upon persistent industrial relations anarchy. 
economics, labour law itself has returned to the mainstream of general law. ${ }^{28}$ The thesis that there had been an (unqualified) "legislative policy ... that industrial disputes should be settled by a specialist court" was never expressed legislative policy at all: there were always some areas in which the employment court did not have jurisdiction, leaving them by default to the traditional common law courts, and there was probably also always an area of overlap. ${ }^{29}$ That is still the situation. ${ }^{30}$..Torts not specified in section 242 are still available to found actions in the traditional High Court, ${ }^{31}$ and personal grievance actions are not available to persons who are not members of a trade union at the time of filing their grievance 32 . Of course there must still be jurisdiction in the traditional Courts for relief from such wrongs. Industrial law, unlike some other divisions of law which have been codified, is historically too young, and developing too continuously, to be successfully codified. When certain areas of it do become clearly seen, the legislature has seen fit to give exclusive responsibility for those areas to the specialist Court. The rest is best left open, lest relief for some wrongs be inadvertently precluded.

The present Act has separated off the arbitral functions of the previous court to an Arbitration Commission, and (largely) removed the tripartite worker and employer representation on the Bench. This is a clear indication to the Labour Court judiciary that the legislation wants them to get on with the business of adjudicating on employment disputes as the parties present the cases and on the agreements the parties have actually reached. It frees the judiciary from the contradictory role previously asked of it, that it be some inappropriate mix of conciliator, mediator, and policy interpreter, in addition to and in the process of actually being an adjudicator. Given this, unions should not be surprised at the increasing so-called 'legalism' of the employment court. ${ }^{33}$

\section{John Hughes - Damages in economic torts ${ }^{34}$}

"It may be that the Government, which must surely have been mindful of the detrimental effect of substantial awards against unions on the overall effectiveness of industrial courts, ..."

Why should the effectiveness of industrial courts depend on substantial awards not being made against unions? The implicit answer is that if the Labour Court punishes the unions for breaking the law as severely as would a traditional Court dispensing black-letter law against 35 employers then unions may refuse to take their industrial business to an

That was the folk wisdom of industrial relations for many years. It was interpreted by some to mean that only the specialist court should settle industrial disputes.

29 The Rodney Harrison/John Haigh travellling New ZealandLaw Society seminar.

30 A point presently being tested in the High Court by Fletcher Construction Ltd.'s $\$ 10 \mathrm{~m}$. damages action against the Northern Labourers Union and officials.

31 As John Haigh correctly points out.

32 Again, Ken Douglas, Evening Post, Tuesday, 24 November 1987.

33 In this context, IR folk lore usually refers to the high dudgeon of the FOL at Blair,J.'s "nil wage order".

34 Hughes, J (1987) Damages in the economic torts New Zealand journal of industrial relations 12 (2) :101-105..

35 Very revealing! It is certainly true that a few years ago one could hear that comment from employers and their advisors. Before 1984, the industrial relations system's conflation of Court arbitration and adjudication was seen as requiring sensitivity from employers not to be too hard 
employment court. What about the business under industrial attack ? The post-1984 attitude is that that business is going to try hard to recover compensation for its wounds. After 1987, it has some marginally clearer tools to use in a court which is both familiar and historically acceptable to the offender - tools such as the more explicit compliance order, the injunction and the economic torts.

\section{Martin Vranken - Applicability of common law in industrial relations ${ }^{36}$}

Vranken's thesis is that "the common law" (and he has in mind particularly damages actions for strikes) "is inappropriate in dealing with industrial action". His reason is that "it risks jeopardising the very concept of the social autonomy of industrial law." The fallacy is the assumption of "the social autonomy of industrial law". Employment law is not uniquely different from conventional law, as is often claimed ${ }^{37}$ From the business point of view, the consumer is paramount; business is the agent of the consumer's satisfaction and the employer the personality of the business; and labour is but one input to the business in providing consumer satisfaction. The notion that industrial law is unique proceeds from the reverse order of priorities : the population collectively must, for humanist reasons, consume (eat, shelter, clothe, warm); consumption requires purchasing power, both for worker-consumers and for the producing business (to move the inventory - the Keynesian 'effective aggregate demand' thesis); purchasing power comes from remuneration; remuneration requires employment; so aggregate consumption requires collective employment. ${ }^{38}$ Industrial law disciplines the employment environment collectively, and so is unique amongst laws in that it is essentially collective. Employers reject that notion. It is the satisfaction of consumer demand which generates the demand for labour and employment. In any event, to argue that collective employment relationships are paramount as shown by the collective jurisdiction of the Labour Court is circular : the Labour Court was constituted to deal with collective relationships. ${ }^{39}$ It is the statute that makes them unique : not vice versa. 4041

on the unions. And some employers thought "suing the pants off" an errant union was being too hard. (Cp. Haigh's article, p.119: " ... but its use in the past has been voluntarily curtailed by employers themselves.") But that attitude has substantially changed since the radical deregulation of 1984 and afterwards. Employers now no longer have the cushions of crosssubsidisation. The true costs of various actions taken against a firm are now more clearly and more quickly seen - by management themselves, and by the owners and the financial analysts who judge the managers. The possible range of success and failure has been tremendously widened : the very good succeed excellently; but the mediocre and the soft touch stick out like sore thumbs.

36 Vrankin, M (1987) The applicability of the common law in an industrial relations context (with special reference to industrial action): a comment New Zealand journal of industrial relations 12 (2) :107-112.

37 See earlier analysis of the Richardson,J, article.

38 The core of the attitude of the CSU's economist, Peter Harris.

39 Within labour collectivities, and between them and employers, both collectively and to some extent individually (personal grievances).

40 Industrial relations are not inherently unique just because behind the collective metaphor there are many individuals relating industriously to many employers. Collective industrial relations and law is an accidental consequence, not a necessary inherent characteristic and cause of, the many employment relationships.

41 The argument that industrial law is, or should be, "socially autonomous" only holds if one believes that the abstract meta-notion of collectivities is more real than its elements. That is,

cont. over. 
John Haigh -Will industrial relations survive the Labour Relations Act $1987 ?^{42}$

Haigh answers "yes". Specifically, "Compliance orders will supersede injunctions as the most effective remedy to prevent ongoing breaches of industrial awards or agreements." If "most effective" means most numerous, I agree. The procedure is not as technical, and so is more easily accessible to a wider range of advocates on both sides. It may be that a compliance order is only really effective because it is backed up by the mysterious "Injunction" which striketh from heaven like a lightning bolt, and the awful "Damages In Economic Tort" suit which can crush the wicked with a burden which robs them of all their financial Enna-G for years to come. Black humour ${ }^{43}$ aside, the effectiveness of the compliance order is in part due to its being seen by boisterous unions as a lesser and less aggressive remedy; and thus somewhat more acceptable to them. 44

All of this goes back to the earlier Hughes thesis that the effectiveness of the Court depends on the "acceptance" of the unions of the remedies meted out. There has been the feeling that if the Court applied the full sanction of the law rigorously, the unions would cease to bring their grievances to the Court and would instead "hit the bricks", which is taken as clearly not "improving" [1973 Act] and not furthering "the orderly conduct" of [1987 Act] good industrial relations. It is even thought it could also lead to the demise of the Labour Court as an institution. ${ }^{45}$ That view over-rates the power and relevance of unions in their present role and attitudes. If the unions choose not to use the Labour Court, employers still could. If union officials defy Labour Court judgments, the unions could face contempt and sequestration orders. If the Labour Court judges refuse to punish

that 'effective aggregate demand' is more real than a purchase of a loaf of bread; that a firm's 'workers' is more real than Sam Browne on the packing belt and Jane Smith in the office of the forge. It hinges on one's socio-political disposition towards individualism or collectivism. Employers prefer individualism, whose ex post facto collectivity is the "market". By ex post facto is meant that the market does not do things. Rather, it is simply an expression for the collective effect of all the individuals in a particular aspect of their behaviour, afterwards. The 'market' is a dependent, not an independent, concept. Talk of the market 'doing' something, such as constraining consumer alternatives, or 'failing', is metaphorical. It may provide seminal insight, but it is not analysis.]

42 Haigh, J (1987) Industrial relations: will they survive the Labour Relations Act 1987 ? New Zealand journal of industrial relations 12 (2):119-121.

43 Humour seems attracted to the topic of injunctions. Horn,CJ complained of suffering from "injunctivitis"; and the abstract to Haigh's paper states "that the heyday of the use of un junctions in industrial law has been and gone." However, the science of industrial relations awaits its Charles Dodgson yet.

44 If an employer wishes to warn a union in a tone of medium severity, it files a compliance order; (if it is more serious, it files an injunction or tort; and if if is totally exasperated, it hangs a damages claim on the injunction or tort). After all, the days or weeks it can take to get a compliance order to Court gives grace for a goodly strike - no swift lightning bolt there; and no damages can be awarded under the compliance order - no crushing weight of punishment
there.

45 Indeed, some employers, unionists, and lawyers have speculated just that as a result of the 1987 Act, saying that: the injunctions and damages actions are too technical, alienating the nonlegally-trained advocates; the injunctions and damages are too effectively punitive; the loss of member's representing worker-employer interests means unions no longer feel they have a 'friend' at Court; the unions can put prompter and more effective pressure on unions through
direct action. 
for disobedience of their orders, there could be appeals or proceedings for review of those decisions in the Court of Appeal. ${ }^{46}$ The 'acceptability' of the Labour Court to one or other collectivity is not critical once the Court is instituted. The Labour Court only exists derivatively to assist the prior reality of grouped industrial relationships - without its exclusive jurisdiction, it is not inherently necessary. The same is true of the unions themselves. They too are derivative, serving the prior realities of employment, business organisation, and consumer demand. If there were no unions, there would still nonetheless be workers working for employers to satisfy consumer needs. The truth is that the unions need the Labour Court more than it needs them. The Court is a major source of legitimisation of the existence of industrial unionism.

\section{Under the Labour Relations Act 1987}

Infancy

It is too early to assess definitively the progress of the Act. There have been many instances of great caution, both judicial and administrative, as is to be expected with a new Act. ${ }^{47}$ However, despite the changes to the statute, to the Court structure and to Court personnel 48 , the IR system today is still made up substantially of the same union officials, company industrial staff, and central organisation advisors as it was before August 1987 . Most of the law before that date continues to be relevant. ${ }^{49}$

\section{Teething troubles}

\section{(a) Procedure : statement of defence}

Unlike conventional Courts, no statement of defence is required to be filed by a defendant or respondent. This not infrequently leads to defence by ambush. The Labour Court is a civil court; it should be looking to the spirit of the the High Court commercial list as a model of requiring promptness and openness from the parties. A start would be to require reply statements which go beyond mere denial of claims and which indicate the respondent's view of the issues, where those differ from the applicant's statement of claim.

\section{(b) Chameleon strikes slide from unlawful to lawful cause}

Consider an employer who is bound by a registered award, is struck outside of the 60 days of the award's expiry, with a claim for a special allowance. After trying to contact, and then reason with the elusive union secretary, the employer contacts his advisors who tell him his primary remedy under the Act (s. 186(f)) is a compliance order. So the employer

46 Indeed, even if unions decided on a wholesale policy of industrial warfare, there are still businesses that must go on and workers who must eat and consumers who will demand satisfaction of their needs.

47 The question of the possibility of ex parte injunctions and compliance orders is one example (the judgment is still awaited from the November 1987 case before the Full Court); the administrative anxiety casued by the early flood of compliance order applications is another.

48 Creating the Arbitration Commission.

49 And so not surprisingly the attitudes underlying the comments in the articles in the New Zealand journal of industrial relations of August 1987 seem still to persist substantially. Hence this paper's criticism of those attitudes and suggestion of an alternative view. 
files a compliance order application in Court. That same afternoon the employer receives a fax from the union's lawyer, which reads (in part) :

As of $2.00 \mathrm{pm}$ today, the union withdraws its strike action for the teaspoon allowance of $\$ 5.00$ per week.

As of 2.05 pm today, members of this union, the ABC IUOW and of two others, the PQR.IUOW and the XYZ.IAOW, employed by your firm are on strike in support of a composite agreement, full details of the claims of which will be forwarded to you soon. Meanwhile, we advise that one of those claims will be for increased remuneration of $\$ 5.00$ per week teaspoon allowance.

Second (or subsequent) level bargaining is alive and well.

(c) Is a compliance order really "the primary remedy for a breach" ?

Two unions have a chronic demarcation dispute history. An employer is in a vulnerable industry, or at a vulnerable time. The first union strikes for an agreement to secure to itself all of the disputed work at that employer. The employer's crop will spoil in 3 days; or the last export ship or flight arriving pre-Christmas in London leaves in 3 days; (or whatever). Even with urgency, the queue of cases means it takes 2 weeks to get a compliance order application before the Court - or one week for an injunction. This is not a commercial response time. Worse, there is some evidence, and a general belief, that the Court administration favours a certain creative delay in letting such applications get heard before a Judge. "Things work themselves out", a little strike massage is inevitable and therefore acceptable, it eases the Court's case load. This is not acceptable administration.

Actually, notwithstanding section 186 (f) and section 230 (e), mediation is really perceived as the "primary" remedy for disputes, even of non-compliance. But what incentive is there on the union to attend urgent mediation (which cannot punish non-attendance), when the enforcement of the mediation procedure is still remote in time? Why not wring out a few more days' industrial pressure?

In the Fletcher Construction v Northern Labourerers Union compliance order case ${ }^{50}$, the Judge held that the evidence was that the cause of the strike by members of the Labourers Union against their contractor-employers (not Fletchers) by refusing delivery of only Fletchers materials (cement, timber, steel) on to Auckland sites, was a demarcation dispute betweeen labourers and engineers over rigging down at Kawerau. The applicants were not the employers of the strikers; so no compliance order could issue at their suit. The strike was "reprehensible", but the Court could offer no compliance order remedy. This was exactly the situation of secondary industrial action for which the Employers Federation pleaded for remedies in submissions to the 1986 Labour Relations Bill.

In the same case, the Judge refered to the Bay Milk case ${ }^{51}$ in which he refused a compliance order application over breach of award through failing to follow disputes procedure, on the ground that "since the demarcation was about to be heard. ... a compliance order could have pre-judged the larger issue ... ". With respect, it is not immediately obvious why the imminent hearing of a demarcation dispute should over-ride sanctity of the requirement agreed upon by the parties to follow set procedures to resolve demarcation disputes. If it is that demarcation is a "larger issue" than following resolution 
procedure, one cannot but ask how a judge 52 can rank a particular dispute of a class of disputes as "larger" than a procedure to deal with all examples of that class. Surely procedure is "larger" than a particular substance; and that a Judge must labour to achieve particular substantive justice within general procedures. ${ }^{53} 54$

The Long Title of the 1987 Act refers to "orderly conduct of" and the 1973 Act to "improving, industrial relations?". If a judicial belief that a union or a group of workers may continue to feel aggrieved and continue industrial action in this or another strike, which is clearly not "good industrial relations", is sufficient ground for a judge to decide not to make a judgment enforcing some particular discretionary remedy of the Act, then employers state strongly that they believe that adhering to procedures in statute or agreed by the parties is also, and more fundamentally, good industrial relations. Whether unions like that or not, or will continue a specific strike, is subordinate to such sanctity of agreement. ${ }^{55} \mathrm{It}$ should be remembered that employers can have "equity" on their side, too. It is hard to believe that the discretion not to issue the compliance order should have been exercised on the grounds of the mere existence of another simultaneous cause.

If a union calls a strike of some of its members, within 60 days of expiry of its award, over two issues, one lawful (say, the re-negotiation of its award) and a one unlawful (say, a demarcation dispute), can (should? would?) the Court issue a compliance order ? This question exposes the conceptual problem of multiple causes of industrial action where the Act expects only single causes. The Court might strive to delve into the facts of each case so as to separate some workers' striking over (say) redundancy from other workers' striking over the disputes of interest. Yet there will, at times, be fact situations with genuinely joint strike issues, one lawful and one unlawful. Will the Court interpret the Act to give priority to continuation of work or to bargaining leverage ? The answer to be given by the Court will be read by practitioners as a policy judgement akin to legislation.A small step towards a solution might be to consider requiring strikers to give written reasons for a strike, with the proviso that where those reasons are shown not to properly identify all the relevant reasons, the strike thereby becomes unlawful. "Reasons for a strike" would redress a present imbalance between strikes and lockouts. Lockouts, in order to justify non-payment of wages, require an employer to lay some demand on the workers 56 If section 233 were amended in that way, it would require a party taking industrial action to provide identification of all the causes of, and thus reasons for, the dispute, which would in itself be a major step towards resolving it. It would also provide the Court with reliable evidence upon which to discriminate between lawful and unlawful action 5758 (However, it is acknowledged that the usual problems of evasion and evidence

Whatever 'fix-it' attitude may be though appropriate to the role of mediator.

54 Grover v Southland Engineering showed that 'equity and good conscience' exists within, and is disciplined by, the statute.

55 After all, the logic of the contrary view is that if employers were correspondingly cavalier towards their statutory duties and industrial agreements, the Court would not grant unions discretionary remedies in case employers may feel aggrieved and continue some industrial action, for example a lockout. "Good industrial relations" is a two-way street which includes adherence to agreed procedures.

56 (s.232(1): "... with a view to compelling ...; and New Zealand Engine Drivers etc IUOW v Gear Meat Processing Ltd AC 42/82).

57 If the amendment added the phrase "and only if" after the first "if", it would settle the present grey question of the legality of strikes which are neither lawful under s.233 nor unlawful under

cont. over. 
exist for unions determined to avoid such provisions.) Identification and evidencing the policy ambiguity as to work continuation and bargaining leverage, does not of itself resolve the contradiction. Employers want a clear legislative statement that striking or locking out over imminent re-negotiations of a dispute of interest is lawful only when that is the only issue in dispute. Confusion with other issues should disqualify that protection.

\section{Conclusion}

Industrial relations theorists have for many years cast industrial relations in a framework of personified classes, workers and employers, whose relations are predicated upon conflict. The so-called 'unitary model' ("let's all bake a bigger cake", "we're all in it together") has been represented as 'pollyanna'. Instead, employers' and workers' different goals have been treated as equally valid (when 'worker' values haven't actually predominated). The following suggests a different view which is believed to reflect better business opinion of priorities. The reason there are any jobs at all, whether in employment or contracting, is that some people called "consumers" want, and are prepared to pay for, some goods or services. Such work is the only reason for jobs. All other so-called 'work' is disguised welfare. It is the function (not the 'right'; but rather the 'duty') of management to meet consumer demand, and to do so as efficiently and effectively as possible. One of the ways for management to meet consumer demand is to organise labour productively and strengthen its muscle and mind with capital and motivation.

Two inferences can be drawn Firstly, management goals/duties are socially more fundamental than those of workers, because they are more totally and immediately related to satisfying consumers. Secondly, and as a corollary, unions would have more leverage with management if they identified means of satisfying consumers which are superior to current management practice (because mangement's clients would then support the workers), than by interfering with consumer satisfaction by interruptions. At present, any apparent union gains from industrial action are usually Pyrrhic.

Strikes almost always ultimately cost workers more than employers, since management has the general support of owners on wider issues above and beyond employment, and can often, in the medium term, remove the employment from New Zealand or transform it to minimise strike affects. Where strike damage cannot be avoided or minimised, the service itself becomes run down or made non-competitive or both. The immediate effect of that is that future jobs are not created, and present jobs are threatened. While not striking will not create employment (that's a different problem), strikes white-ant employment. ${ }^{59}$ The more open New Zealand's economy, the more de-regulated its markets, then the more essential is union leadership which improves its members' remuneration and conditions by making suggestions on management and direction which are better than the present

s.234. Strikes would only be lawful if reasons were stated and confirmed in writing : without that minimum, strikes would be unlawful, removing an element of present ambiguity. That would parallel the effect of "with a view to compelling" in s.232 - "Definition of lockout".

e.g. compare Small's evidence on collateral 'fix-it' demands at p.11 of Feltex v New Zealand Engineering, and Northern Distribuition, Unions LC.70/87 and Williamson,J.'s quoting of New Zealand Engineering IUOW v New ZealandMC Ltd. [1983] ACJ 73, in Air New Zealand Ltd v New Zealand Air Line Pilots Association IUOW LC 22/87, p.14 (re comment on ARA v Public Passenger Transport Workers). its members' self-abuse : it hits them in their pockets. 
practices of management and boards. That requires a totally new attitude in unionism. Workers might hire as union officers, some of the very brightest graduates and some very experienced technicians. These people would analyse and comment. They probably wouldn't stay long with the unions (but so what ?); and the best of them might see critiqueing employer performance for a union as a good "shop window" for demonstrating their executive potential. Effective, incisive union officials of that stripe would be snapped up as managers and directors as just the sort of entrepreneurial go-getters owners of capital would want to manage their enterprises. The spin-off is that unions then have some of "their own" in the ranks of management. The breakdown of industrial apartheid is begun. 60 In such a competitive, innovative, mobile environment, how much need do you think there would be for a (opportunity-)costly seminar such as this on "Strikes and the Labour Court : the Injunction and Compliance Order Provisions ..." ?

60 Some unionists seem to have become bogged down in totally the wrong job. Their energies, insights, drive and visions have been drowned in the mediocrity of union politics and polemics. What a waste that no-one had hauled them out of the morass and set them to managing something - they could have been getting paid to create, instead of depress, jobs. 


\section{RELATIONS INDUSTRIELLES INDUSTRIAL RELATIONS}

Revue trimestrielle bilingue publiée par le Département des relations industrielles de I'Université Laval, Québec, Canada - A quarterly bilingual Journal published by the Département des relations industrielles, Université Laval, Québec, Canada. Directeur - Editor: Gérard Dion.

\section{SOMMAIRE - CONTENTS Volume 43, numéro 1,1988}

Paradigmes, écoles de pensée et théories en relations industrielles Michel AUDET et Viateur LAROUCHE

Industrial Relations Theories

The New Industrial Relations in the US: Phase II Jack BARBASH

Les nouvelles relations industrielles aux Etats-Unis: Phase II

Changing Environments and Management IR Practices. Implications for

U.S. Trade Unions

Yonatan RESHEF

Le milieu changeant et les pratiques des employeurs en matière de relations de travail: leurs conséquences pour les syndicats américains

The Appropriate Bargaining Unit: The Need for Policy Consistency by Canadian Labour Boards

David C. McPHILLIPS

L'unité de négociation appropriée: la politique d'uniformité des Commissions des relations du travail canadiennes

Une méthodologie de comparaison des salaires pour les emplois spécifiques du secteur public

Jean-Michel COUSINEAU et Yves RABEAU

A Methodology of Wage Comparison for Specific Occupations in the Public Sector

Economic Aspects of Mandatory Retirement. The Canadian Experience Frank REID

Les aspects économiques de la retraite obligatoire: l'expérience canadienne

Workplace Relations, Skills-Training and Technological Change at Plant-Level Adrian CAMPBELL and Malcolm WARNER

Les relations du travail, la formation et les changements technologiques au niveau de l'établissement

What Do Workers Want? Attitudes Towards Collective Bargaining and Participation in Management

John RICHARDS, Gary MAUSER and Richard HOLMES

Que veulent les travailleurs? Leurs attitudes vis-à-vis la négociation collective et la participation à la gestion

Une analyse des comportements de travailleurs masculins et féminins selon deux formes d'absence au travail

Robert R. HACCOUN et Serge DUPONT

An Empirical Analysis of the Activity Patterns of Employees who are Absent or on a Vacation Day

Operative and Espoused Personnel Selection Criteria of Managers

Jang B. SINGH and Olga CROCKER

Critères opérationnels et critères favorisés de sélection du personnel chez les dirigeants d'entreprises

\section{DISCUSSION}

Line, staff et functiona

Raymond PEPERMANS

Décisions rendues par le Conseil canadien des relations du travail Johane TREMBLAY

Changements dans les légisiations du travail au Canada

Michel GAUVIN et Geoffrey BRENNAN

Recensions - Book Reviews

Publications récentes - Recent Publications

Livres reçus - Books Received

Abonnements annuels - Annual Subcriptions - Institutions: \$48.00; Individus - Individuals: Canada, \$24.00 Etranger - Foreign: \$26.00. Le numéro - Single Issue \$7.00 - Les Presses de I'Université Laval, C.P. 2477 Québec, Qué. Canada, G1K 7R4 